\title{
Fim de tarde
}

Ibéria de Souza FARIAS*

... E a nossa música se fez...

Nos sons dos lábios se tocando,

No pulsar do coração...

E o vento que soprava suas notas,

Soprava como em segunda voz...

As folhas das árvores batiam palmas,

Mas batiam baixinho, para não atrapalhar.

Eles nos observavam, como mesmo a contemplar...

Até os pássaros que entoam lindas notas...

Preferiram se calar.

Até o céu com sua voz suave,

Preferiu somente olhar...

Por medo de errar a nota,

E nos fazer desconcentrar...

O céu quis aprender como se louva,

Então ele conteve a sua voz...

E com um sorriso bem baixinho,

Sussurrou com vento para nós:

"_ Esta é a mais linda melodia que já ouvi,

Não tenho como explicar,

Peço que ensinem para mim,

E se preciso vou chorar.

Tenho observado muita gente,

E sou um bom observador,

*Graduanda em Letras (Língua Portuguesa) pela Universidade Estadual da Paraíba (UEPB). E-mail: iberiafarias@yahoo.com.br 
Vocês cantam com a alma...

E vossas almas cantam com louvor..."

Senti um frio imenso,

Nossas mãos estavam geladas,

Era o céu nosso aprendiz

Querendo entender o segredo que se entoava.

Somente aquietou-se quando

Chegou a despedida,

E, ainda assim, disse: "__ Até a próxima vista!" 